\title{
Global Health and Planetary Health: perspectives for a transition to a more sustainable world post COVID-19
}

\author{
Saúde Global e Saúde Planetária: perspectivas para uma transição \\ para um mundo mais sustentável pós COVID-19
}

\author{
Gabriela Marques Di Giulio (https://orcid.org/0000-0003-1396-9788) ${ }^{1}$ \\ Eliseu Alves Waldman (https://orcid.org/0000-0001-7807-6898) ${ }^{2}$ \\ João Nunes (https://orcid.org/0000-0002-0118-0993) ${ }^{3}$ \\ Paulo Marchiori Buss (https://orcid.org/0000-0002-9944-9195) 4 \\ Patricia Constante Jaime (https://orcid.org/0000-0003-2291-8536) ${ }^{5}$ \\ Tereza Campelo (https://orcid.org/0000-0002-9905-9453) ${ }^{6}$ \\ Helena Ribeiro (https://orcid.org/0000-0002-1321-7060) ${ }^{1}$
}

\footnotetext{
${ }^{1}$ Departamento de Saúde Ambiental, Faculdade de Saúde Pública, Universidade de São Paulo. Av. Dr. Arnaldo 715, Cerqueira César. 01246-904 São Paulo SP Brasil.ggiulio@usp.br ${ }^{2}$ Departamento de Epidemiologia, Faculdade de Saúde Pública, Universidade de São Paulo. São Paulo SP Brasil.

${ }^{3}$ Departamento de Ciência Política, Universidade de Iorque. Iorque Inglaterra. ${ }^{4}$ Centro de Relações Internacionais, Fundação Oswaldo Cruz. Rio de Janeiro RJ Brasil.

${ }^{5}$ Departamento de Nutrição, Faculdade de Saúde Pública, Universidade de São Paulo. São Paulo SP Brasil.

${ }^{6}$ Faculdade de Saúde Pública, Universidade de São Paulo. São Paulo SP Brasil.
}

\begin{abstract}
The manuscript discusses interfaces between academic and practical fields of Global Health and Planetary Health, shedding light on some critical perspectives of cumulative and synergistic causes of global crises, and effects on health and food security, on human rights, on migration, and on environment. Concepts of Global Health and Planetary Health and the path for the Sustainable Development Goals -SDG in the context of the Syndemy of Global Crisis, in particular the COVID-19 pandemic, are presented. COVID-19 lessons highlight challenges of infectious diseases and pandemics of the crisis of food insecurity, and of climate emergency. The manuscript advocates for an innovative approach that simultaneously broader awareness of the interconnected problems and of their complex causes and calls for emancipatory knowledge to face urgent challenges for a transdisciplinary research agenda aiming to tackle enormous planetary problems brought by the Anthropocene. It calls for practical solutions, with examples of some nature-based. It highlights the need of a collective reflection on a viable path to promote changes for a more sustainable, equitable, and adaptive future, bridging gaps from Global and Planetary Health.

Key words Global health, Planetary health, Food security, Sustainable development, Epidemic
\end{abstract}

Resumo O manuscrito discute as interfaces entre os campos acadêmico e prático da Saúde Global e da Saúde Planetária, lançando luz sobre algumas perspectivas críticas acerca das causas cumulativas e sinérgicas de crises globais e seus efeitos na saúde e segurança alimentar, nos direitos humanos, na migração e no ambiente. São apresentados os conceitos de Saúde Global e Saúde Planetária, e perspectivas para os Objetivos de Desenvolvimento Sustentável (ODS) no contexto de uma sindemia de crises globais, em particular a pandemia de COVID-19, cujas lições lançam luz sobre os desafios relacionados às doenças infecciosas, crise de insegurança alimentar e emergência climática. O manuscrito defende uma abordagem inovadora que, simultaneamente, amplie a consciência dos problemas interligados e de suas complexas causas e fomente o conhecimento emancipatório para enfrentar os desafios urgentes de uma agenda de pesquisa transdisciplinar visando enfrentar os enormes problemas planetários trazidos pelo Antropoceno. Reforça a necessidade de soluções práticas, com exemplos de soluções baseadas na natureza, e de uma reflexão coletiva sobre um caminho viável para promover mudanças para um futuro mais sustentável, equitativo e adaptável, preenchendo as lacunas da Saúde Global e Planetária. Palavras-chave Saúde global, Saúde planetária, Segurança alimentar, Desenvolvimento sustentável, Epidemia 


\section{Introduction}

COVID-19 pandemic added enormous difficulties to global sustainable development. Economies were paralyzed, prospects for recovering postponed, hunger and food insecurity increased. The pandemic highlighted and amplified social, economic, and environmental problems. It underscored a complex syndemic scenario, with health and climate emergencies interacting to impact human life. Interconnected risks are closely related to development, with globalization, technological advance, rampant deforestation, loss of biodiversity, unsustainable exploitation of land, water, forests and oceans, and prevalence of unhealthy cities. The health field witnesses examples of human behavior interacting with development of viruses and other biological entities, and of diseases interaction.

Addressing these challenges demands a multidimensional perspective on sustainability, privileging cultural diversity, solidarity with the planet, ethical values and equity, rights, justice, and autonomy ${ }^{1}$. It goes far beyond Agenda 2030', and efforts made in last 30 years, since United Nations-UN conferences focused on dimensions of development to "prepare the world for the 21st century". The relative success of the Millennium Development Goals (MDG) stimulated the UN and Member States to maintain consensual global and national development goals. The deepening of the environmental crisis, and the growing pressure from civil society, led to deepen the 'sustainable development' strategy, with new more ambitious goals (the Sustainable Development Goals - SDG) to be effective by 2030. Several reports since 2016 showed that - despite the global commitment to a sustainable, equitable and inclusive development model - and the slogan 'leave no one behind' - poor performance of developed countries' commitment to financing the SDG, coupled with a permanence of a non-sustainable development model, accelerated global, regional and local poverty and inequalities in most countries. During COVID-19 pandemic, while most heads of UN agencies and of some multilateral agents emphatically reaffirmed that social, economic and environmental recovery may be possible only through the 2030 Agenda, the noisy silence of the leaders of International Financial Institutions, such as the IMF - International Monetary Fund, and the World Bank, regarding the 2030 Agenda in the new context has been prevalent.

The Global Health and Planetary Health perspectives can shed light on these questions. The emergence of global health as a field signaled a growing recognition of interdependence in patterns of circulation of diseases, and of a growing network of governance mechanisms that can be mobilized to tackle health problems. Global health was originally connected with a worldview according to which 'diseases know no borders' and the world is marked by a commonality of conditions for responding to cross-border threats ${ }^{3}$. In recent years, critical studies on global health have reconfigured preexisting ideological, geopolitical, and methodological disputes in the international arena of health ${ }^{1}$. These studies bring together knowledge, teaching, practice and research regarding health issues that exceed national geographical boundaries; their social and environmental determinants; as well as possible solutions that require interventions and agreements among different stakeholders, including countries, governments, international public and private institutions ${ }^{4}$.

Planetary Health assumes that health problems and definition of public policies to tackle them cannot be separated from the current ecological emergencys. The latter is a climate emergency related to rampant loss of biodiversity, environmental degradation, and depletion of resources. Importantly, ecological emergencies also include a profound crisis of human systems and socioeconomic organization. The emergency stems from the interaction of different dynamics of destruction and domination, which include but are not limited to the encroachment of private interests in public and global commons; and new forms of dispossession and exploitation, including colonialism and slavery in old and new guises. Arguing that many visions in the global health field tend to elide the perpetuation of inequalities in health, planetary health calls for a broader and more profound awareness of the interconnected problems affecting global health, and their complex causes. Planetary health demands a paradigm shift in how we conceive health and disease. Analytically, it calls for a deepening of a syndemic knowledge, recognizing the interconnection of health and environmental problems, socioeconomic dynamics and how they impact groups differently. Normatively, it calls for emancipatory knowledge, including: decoloniality, and a clear project towards dismantling institutional and structural racism; feminist and non-binary knowledge, which resists and subverts heteronormative and patriarchal structures of power; and an ecological perspective to promote solidarity across and within borders, including transformation of the rhythms and patterns of behavior in individual and communal life. 
In common, both concepts of Global Health and Planetary Health directly engage with critical challenges in the 21st century: the unequal distribution of diseases around the world; the impacts of global environmental changes on human health; climate mitigation and adaptation; existing patterns of consumption and waste; the growth of xenophobia, racism, misogyny, and transphobia; and the economic, political and social tensions regarding policies, institutions and systems. Using this two-pronged perspective, this article discusses some challenges that impact upon health.

\section{Infectious diseases and pandemics - lessons from COVID-19 crisis}

Infectious diseases accompany men since primordial times and dispersion started when propitious conditions for infectious agents were achieved, through continuous transmission from person to person or person-animal-person ${ }^{6,7}$, with the first human settlements, and domestication of animals for regular food source ${ }^{6,7}$. Continuous close contacts between men and animals favored the transfer ("jumps") of microorganisms that circulate in animal populations to men, explaining, at least in part, why close to $60 \%$ of infectious agents are from animal origin ${ }^{7}$.

Infectious diseases were responsible for frequent epidemics by new infectious agents, some with potential to become pandemics. With hunger and wars, infectious diseases constituted, historically, the main flagella of humankind, helping to mold the course of history and causing immeasurable deaths and increasing misery ${ }^{8-11}$.

There are many registers in history of pandemics or large epidemics, e.g. the Athens Pest (Century 5th AC), the Justinian Pest (Century 6th DC), the Bubonic Pest (Late Middle Age) and the Spanish Flu (1918). Until the 20th Century, the intervals between the pandemics were centuries or many decades; from the 1980s, these events increased in frequency and intensity to levels unrecorded, namely HIV (1981), Sars (2002), H1N1 (2009), Ebola (2013), Chikungunya (2014), Zika (2015) and COVID-19 (2019) 7 .

This fact counteracts the rapid transformations of the 20th Century, with expressive fall in mortality by infectious diseases and increase in life expectancy as consequence of amplification of basic sanitation, introduction of new medical technologies (vaccines and antibiotics), improvement in nutritional, housing and working conditions ${ }^{10}$. While these improved wellbeing and increased life expectancy of large part of humans, they created conditions that put at risk the survival of humankind ${ }^{10}$. Accelerated population growth and urbanization, expansion of consumption of industrialized food, complex systems of mass transport and impressive increase of international exchange of people, introduction of methods of intensive feed for animals, environmental and climatic changes, global warming, deforestation and biodiversity loss, associated to an incredible capacity of mutation and recombination of microorganisms, created ideal scenarios for emergency of potentially pandemic microorganisms ${ }^{7}$. This lead to reintroduction of priorities of infectious diseases in public health policies, especially, the emergent with pandemic potential, due to its great social impact around the globe ${ }^{9,10}$.

Alerts appeared by the end of 20th Century ${ }^{12}$ with new proposals of global surveillance and reform of the International Sanitary Regulation (ISR) in $2005^{13}$. Based on the new ISR, the World Health Organization (WHO) recommends that member countries make surveillance and the structure of health services more robust, and effective in face of public health emergencies ${ }^{14}$. Four pillars are critical: i) a basic network of universal access services with capillarity; ii) surveillance with ability to quickly identify events with potential to create local, national, or international emergencies, iii) capability of identifying the need for knowledge production of strategies or to support interventions; and iv) governance with capacity to assume coordination and internal and external articulation to ensure effective and coherent conduct between public and different health institutions, public and private. The control/mitigation strategies and the articulated actions of these four pillars require surveillance analyses of the complex interaction of biological, social, political, demographic, and economic factors, each of them obeying its own dynamics ${ }^{15}$.

Considering that behavior of infectious diseases is, to large extent, conditioned by human behavior, and the relevance of zoonosis in the emergence of potentially pandemic infectious agents, it is critical to analyze: i) contact between people, and their determinants (e.g. urbanization, migrations, population growth, increased international exchange); (ii) contact between animal and humans and its constraints (e.g. environmental changes, introduction of new intensive breeding techniques, intensive use of industrialized food); (iii) the evolutionary process of microorganisms and their natural determinants 
and those induced by the application of health technologies ${ }^{7,10}$.

The integration of these 3 factors, adopting the "One Health" strategy ${ }^{16}$ is critical to better understand determinants and impacts of the current pandemic of COVID-19. Among challenges faced, there are insufficient knowledge about clinical characteristics, immune response, therapy and epidemiology, and lack of preparedness of health systems in all countries. The rapid spread across the globe and significant increase in morbidity and mortality lead to the collapse of health systems in several countries. The long duration and the occurrence of several waves of increasing incidence prove the resilience of health systems and their professionals, while highlighting the lack and/or failures of health systems in relation to the four pillars in various countries.

While most all the capacity of health services have focused on the care of COVID-19 cases, the follow-up of chronic patients (diabetics, hypertensive, chronic pneumopaths) and early diagnosis of cancer were reduced all over the world, increasing avoidable deaths. High-income and some middle-income countries faced these challenges through more intensive use of telemedicine and other new information technologies. For similar reasons, there was also a drastic drop in vaccination coverage, creating conditions for the emergence of several epidemics, further aggravating the vulnerable situation of health systems. There are also medium and long-term impacts of the pandemic on the health system because of the need for continuous follow-up of patients with different sequelae, mostly permanent of COVID-19.

The impact of the pandemic on life expectancy in several countries, due to excessive mortality, is a serious setback to the advances achieved in middle and low-income countries. While the fall in fertility has been a critical consequence of the pandemic in the demographic structure of countries, and the closure of schools has created irreparable losses for an entire cohort of children, the intensification of social disparities and the food insecurity of many individuals are the most serious impacts that seriously jeopardize human rights.

\section{Food systems and food insecurity}

Two points are highlighted regarding food systems: the neglected scientific evidence on the impacts of current food systems; and the tech-fix solutions on the table to transform our food sys- tems. The impact of food systems on planetary health is alarming: $27 \%$ of global forest losses can be attributed to the production of commodities; food production and consumption are main causes of biodiversity loss; they are responsible for around $30 \%$ of greenhouse gas emissions, and the consumption of $70 \%$ of global freshwater reserves, among other impacts related to agricultural practices.

However, the intense and accelerated food production process that has been devastating the planet does not feed everyone in a healthy, sustainable, and adequate way. Today, the world faces a double burden of malnutrition. Before the COVID-19 pandemic, 2 billion people did not have regular access to healthy and sufficient food, and around 800 million were hungry in a world that has the capacity to produce and feed everyone $^{17}$. Simultaneously, 650 million people were with obesity and exposed to diet-related risks. Despite such shocking numbers, the urgent need to reverse today's predatory food systems has been neglected. The debates on World Climate, in April 2021, for example, focused on energy and transport. Likewise, most countries proposed actions to address climate emergency mainly in these two sectors. Food marginally remains in the debate about the Green New Deal, the green transition, or green solutions.

Secondly, the search for solutions based on high technology became more common and dangerous. Lab-grown meat is a good example of magical solutions. In name of making meat consumption more sustainable, as meat production is driver of deforestation, laboratory meat consumption, paradoxically an ultra-processed food, has increased. Good solutions for food systems and food insecurity must consider: i) the Precautionary Principle, which should guide new solutions that have unknown consequences; ii) solutions based on high technology put the future of food production in hands of big food corporations, which are the main responsible for current unsustainable hegemonic models; iii) such solutions tend to displace real food, freshly prepared meals, and traditional cooking. This combination has caused nutritional, social, and cultural disruption, increased obesity, and other diet-related diseases.

It is critical to analyze factors that facilitate promotion of large, centralized and even expensive interventions, based on engineering and technologies, rather than efforts in behavior change and regulating private sector. The excuse is often associated with the urgency of planetary 
issues, which require fast solutions. However, the proof that it is possible to change behavior in short term is the speed with which big food industries convinced individuals to eat junk food instead of real food in few decades.

Another critical issue is admitting that there are good and bad foods that affect our health and environment in different ways - contrary to the industry's arguments. Ultra-processed products need to be recognized and regulated considering their impacts on health and environment. Governments and UN agencies must recognize that food industry will not regulate itself and lead the change towards healthy and sustainable food systems.

As Bittman stated you can't have a serious conversation about food without talking about human rights, climate change, and justice ${ }^{18}$. Increasingly, there is awareness of impossibility of guaranteeing food security, promoting healthy and sustainable diet, and to prevent and control malnutrition in all its forms, without discussing food systems, social justice, global health, and sustainability. Food security is the stable access to adequate and healthy food for all people, always. Promoting food security requires a combination of global, national, regional, and local policies, and strategies that aim to give everyone ways of eating well, paying attention to the sustainable use of natural resources, environmental protection, the traditional culinary and gastronomic culture $^{19}$.

As other countries, Brazil, which gained attention for reducing hunger and poverty, has observed, in recent years, inflections in public policies with negative impacts on food security. Brazilian efforts in the past resulted of policies for improving food access, income generation, supporting food production by small farmers, and enhancing food security governance. Alongside, Brazil built a robust legal and institutional framework for food security, transforming the fight against hunger into a state obligation, pursuing new objectives related to preventing obesity and promoting healthy and sustainable diets ${ }^{20}$. It resulted from a longstanding mobilization that brought together organizations, networks and social movements, and researchers since the 1980s. Political commitment grew with priority for food security in $2002^{19}$, engaging government and civil society. Investments and use of data of public information systems and scientific evidence played key role, in pointing different aspects of malnutrition: food and nutrition security, hunger, breastfeeding, and obesity ${ }^{21}$. New challenges in the agenda were to foster healthy and sustainable dietary practices, in agreement with the $\mathrm{SDG}^{22}$. A policy response for these challenges was an innovative strategy for the promotion of individual, collective and planetary health, the National Dietary Guideline to support the reorientation of food systems and the control of malnutrition in all its forms, including undernutrition, obesity and dietary risks, which are the leading causes of poor health globally ${ }^{23,24}$.

The Dietary Guidelines for the Brazilian Population published by the Ministry of Health in $2014^{25}$ promotes consumption of healthy minimally processed food, such as varieties of vegetal foods, reinforces Brazilian staples beans and rice, suggests modest amounts of animal foods, and reduction of ultra-processed foods as much as possible. It states that the more ultra-processed foods eaten or drunk, the greater the risk of consuming excessive sugar and unhealthy fats, and inadequate protein. Ultra-processed foods also contain many additives which, while used legally, have unknown or uncertain effects on health. Their consumption discourages family farming, decreases biodiversity, threatens natural resources, increases solid waste, and replaces genuine food crops $^{26,27}$. The principles and recommendations of the Guide influenced official food and nutrition policies and programs of other countries, a successful case of policy diffusion and transfer and example of progressively ensuring human right to adequate food. Unfortunately, there is a recent worsening of the double burden of malnutrition, hunger, and undernutrition, aggravated by overweight and obesity. This represents a return to problems of the past century, exacerbated by the COVID-19 pandemic.

\section{Climate emergency and urgency to act}

Globally, countries, cities, governments, and populations are facing significant risks from climate, including changes in air temperature and precipitation, increased intensity and frequency of natural hazards as floods, landslides, heat waves, sea level rise, that compromise utilities as electricity, water supply, health, and emergency services $^{28}$. Climate change is a condition of our time $^{29}$, with serious impacts that simultaneously interact with and exacerbate other important contradictions in our societies, including socioeconomic inequalities, access to goods and services, pollution (of soil, water, and air), access to food and water, and human rights. Increased social and environmental vulnerability to ex- 
treme climatic events placed climate emergency ${ }^{30}$ as an urgent challenge for decision makers and societies $^{31}$. From the global and planetary health perspectives, it is critical to consider the synergy between climate change with other crises, including the loss of biodiversity, COVID-19 pandemic, and the institutional trust and responsibility $\operatorname{crises}^{32-35}$. It is also critical to analyze interdependence between health, economic development, environmental degradation, governance, and human rights, shedding light on the interactions between policy norms, regulatory frameworks, collective actions, and individual perspectives; seeking to mitigate the cumulative and synergistic effects and the amplification of vulnerability conditions.

Regarding climate emergency, two issues are closely related to global and planetary health. First, the global-local interactions of climate, and the fact that adaptation actions are primarily local and context-specific. Secondly, the urgent need of a commitment with sustainability as a path to promote changes for a more adaptive future.

During the Leaders' summit on climate, in April 2021, the US President declared that humankind is in a decisive decade for tackling climate change. The summit engaged governments that announced their commitments to reduce emissions, including green economy efforts, and concrete and immediate actions to prevent deforestation. Besides the necessary countries' mitigation efforts to reduce Greenhouse Gas emissions (GHG), there is a pressing need to plan adaptation and interventions at local level where people live and are affected. This is a socio-environmental-political process ${ }^{36}$, closely dependent on the willingness to undertake adaptive measures, on availability of and ability to deploy resources appropriately, and on facilitating or hampering consolidation of initiatives.

Cities play an important role in dealing with climate crisis, in accelerating land use transformations and space management, and in leading efforts to push lifestyle changes. Cities are critical locus for experimentation, for testing new solutions, and implementing strategies ${ }^{37,38}$. However, political-short termism, complacency towards climate change, lack of motivation, insufficient resources or access to finance, lack of technical capacity, insufficient information, inadequate policy incentives, political leadership, funding, stakeholder engagement, science-policy interaction, and public support are constraints to urban adaptation $^{39,40}$.
Regarding the SDG, an important learning from the multiple crises, is the urgency of adopting a critical perspective of sustainability, which strengthens a transformative new path capable of abandoning the political, social and economic New Deal ${ }^{41}$. Such understanding, which includes solidarity and shared responsibility for the planet's resources, human rights and a revised production and consumption models, is crucial.

Crises are direct consequences of human activity $^{42}$. Dealing with these crises requires strengthening and enforcement of environmental regulations, stimulus packages that offer incentives for more sustainable and nature-positive activities, funding health systems and incentivizing behavior change, which means rethinking the way that we interact with other species and the planet. A critical perspective of sustainability means inclusion, justice, awareness of differences and a reconsideration of current economic models based on incessant growth, consumption, and waste $^{43}$. It also includes solutions'- oriented planning for sustainability, based on nature.

\section{Nature based solutions and green infrastructure}

Despite the homogenizing trend in cultures due to globalization, different populations, migrants from various parts of the world, and huge inequality in income distribution tuns impossible a universal concept of wellbeing in the life course. The concept encompasses multiple meanings, from individual feelings to solve personal or family problems, to the satisfaction from consumer goods. In the sphere of external conditions, adequate sanitation, energy, drinking water; mobility infrastructure; practices and access to culture, health services, education, public safety, and social life; political stable organizations and accessible justice are essential attributes to well-being. On top of the external conditions, well-being is based on the physical, mental, and spiritual equilibrium ${ }^{44}$.

A body of research points to benefits for Mental Health of living with nature ${ }^{45}$. Recent studies highlight the role of vegetated surfaces, which has ties to biodiversity, climate change mitigation and COVID-19 pandemic ${ }^{46}$. Positive impacts of the environment on well-being might foster a reflection on a viable path to promote changes for a more sustainable, equitable, and adaptive future for the planet and for humankind.

Biodiversity from natural ecosystems provide many benefits and services to the planet. Loss of 
biodiversity is recognized as a planetary phenomenon. Few publications relate biodiversity to the COVID-19 pandemic and wellbeing ${ }^{47}$, showing the intrinsic relationship of the virus outbreak to biodiversity and for healing. Over $40 \%$ of all medical drugs and $70 \%$ of those used as antibiotics and anticancer have origin on biodiversity ${ }^{51}$. Biodiversity is also used in drugs against thrombus, microbes, and viruses. However, the development of antiviral drugs for new diseases is complex, expensive and demands solid scientific investigation. Natural vegetation is also important driver to minimize climate changes but is at serious risk under accelerated deforestation and land use changes ${ }^{48}$. Thus, it is urgent that actions taken by governments and population against the COVID-19 pandemic and to minimize its effect do not amplify the risks of future disease outbreaks and crises.

Glikson $^{52}$ assumes that man has a biological urge to come in touch with different types of environments. It belongs probably in the same category of the physical demand for a variegated nutrition, and the physic demand for variegated social contacts. In his view, a modern urbanite might be considered undernourished in respect to the environment and needs recreational mobility. Change of environment is a need felt in all temporal frameworks of life: during the day, the day itself, the week, the yearly seasons, and lifetimes. The family house or schools serve recreational needs during parts of the day; the public gardens, squares, playgrounds, amusement, and cultural centers for daily and some weekly recreational needs; the city surroundings with parks, forest, rivers for weekends and vacations at different seasons of the year. The recreational areas in and around cities are important for physical health and mental equilibrium, and additionally are socially essential as they are places where community bonds are formed during leisure time. Growing problem of depression, anxiety and stress has, at least in part, been attributed to the increasing disconnect between people and the natural world, supported by research that shows that interactions with nature promote psychological restoration, improved mood, improved attention, and reduced stress and anxiety ${ }^{45}$.

Frumkin ${ }^{46}$ analyzed the role of nature-based solutions for mental health problems, including the therapeutic role for people who suffered brain accidents, and as an important tool to diminish violence and crime in overcrowded neighborhoods. Slums are characterized by lack of space, obsoleteness of flats or houses, and by children and adults escaping their dwellings and filling streets. Since they do not meet in properly dimensioned squares or gardens and are compressed in narrow streets or yards, the nearness of one to another stimulates friction, quarrels among them ${ }^{49}$. A slum quarter, therefore, requires larger public gardens and squares for public facilities.

Town dwellers in better economic conditions, on the other hand, constitute a nuisance or even a problem for the countryside. Nature recreational use has received a large surge during the COVID-19 pandemic. This has a relation, first to home office, which became viable for some categories of workers, mainly those with higher income; second to the desire to get away from crowded cities and from higher risk of contagious. As example, a Real estate app, registered, in the state of São Paulo, Brazil, from February 2020 to February 2021, an increase of $154 \%$ in demand for properties in the interior, of $47 \%$ at beachside, and a decline of $9 \%$ of demand in the capital city ${ }^{49}$. This phenomenon was registered in other world cities, such as New York and outskirts. The migration of people and enterprises, at first, might look like a positive return to nature and a downsizing of urban areas, but its planetary health effects must be studied in full complexity. One of the biggest threats, might be opening large condominiums and resorts on rural and wild areas, transforming natural environment, destroying biodiversity, and pushing agricultural activities to forested areas or to farther less fertile soils, where there is need of more chemical products for maintaining productivity and more fossil fuel use for transport.

\section{Conclusions}

These crises and their effects have clearly shown the complexity of new responses, and clearly suggested the need for a reorientation of values, and a reorganization of power and responsibilities. From a critical perspective of Global Health and Planetary Health, the focus on the interdependence between health and the Anthropocene clearly identifies the limits of technological solutions to respond to global crises. We must better understand the interactions between regulatory frameworks, decision-making processes, collective actions, and individual perspectives to cope with them.

However, these crises might be opportunities to catalyze processes of social change, as re- 
al-time experiments in downsizing the consumer economy, and accelerating transformations. The crucial questions here are: as a collective, do we really want to do that? Do we have conditions to push this transformative agenda? Are we aware that we must tackle these planetary challenges brought by the Anthropocene?

To this end, it is essential to revitalize and strengthen global multilateralism, as is the case with the UN and its agencies, and, in Latin Amer- ica, to reconstruct multilateralism destroyed by conservative governments that took power in key countries in the region, like Brazil. There seems to be a reasonable global consensus that the 'new normal' should not be a return to the 'old normal', but rather the paradigm of the Agenda and its SDGs and the effective commitment to achieve them, by the same countries that have decided to pact it in 2015 .

\section{Collaborations}

GM Di Giulio and H Ribeiro conceived the original idea of the paper and led the drafting process. All co-authors co-designed, co-wrote, reviewed, commented and edited all sections over the various drafts of the manuscript. 


\section{References}

1. Ventura DFL, Ribeiro H, Giulio GM, Jaime PC, Nunes J, Bógus C, Antunes JLF, Waldman EA. Desafios da pandemia de COVID-19: por uma agenda brasileira de pesquisa em saúde global e sustentabilidade. Cad Saude Publica 2020a; 36(40):e00040620.

2. United Nations (UN). Beyond 2015. Department of Economic and Social Affairs. [cited 2021 Jul 28]. Avaliable from: https://sdgs.un.org/statements/beyond

3. Zacher MW, Keefe TJ. The politics of global health governance: united by contagion. Springer; 2008.

4. Fortes PAC, Ribeiro H. Saúde Global em tempos de globalização. Saude Soc 2014; 23(2):366-375.

5. Horton R, Beaglehole R, Bonita R, Raeburn J, McKee $\mathrm{M}$, Wall S. From public to planetary health: a manifesto. The Lancet $2014 ; 383(9920): 847$.

6. Satcher, D. Emerging infectious: getting ahead of the curve. Emerg Infec Dis 1995; 1(1):1-6.

7. Morens DM, Daszak P, Markel H, Taubenberger JK. Pandemic COVID-19 joins history's pandemic legion. mBio 2020; 11(3):e00812-20.

8. Lederberg J. Infectious Diseases - A Threat to Global Health and Security. JAMA 1996; 276(5):417-419.

9. Morens DM, Folkers GK, Fauci AS. The challenge of emerging and re-emerging infectious diseases. Nature 2004; 430:242-249

10. Fauci AS, Morens DM. The perpetual challenge of the infectious diseases. N England J Med 2012; 366(5):454-461.

11. Cummings MJ, Wamala JF, Komakech I, Malimbo M, Lukwago L. Emerging and reemerging epidemic-prone diseases among settling nomadic pastoralists in Uganda. Acta Trop 2014; 137:19-24.

12. Lederberg J, Shope R, Oaks SC. Emerging infections: microbial threats to health in United States. Washington: National Academy Press; 1992.

13. Fidler DP, Gostin L. O. The new International Health Regulations: An historic development for international law and public health. J Law Med Ethics 2006 34(1):85-94

14. Ong AK, Heymann DL. Microbes and humans: the long dance. Bull World Health Organ 2007; 85(6):422.

15. Cherkasskii BL. The system of the epidemic process. J Hyg Epidemiol Microbiol Immunol 1988; 32(3):321328.

16. Bedford J, Farrar J, Ihekweazu C, Kang G, Koopmans $M$, John Nkengasong J. A new twenty-first century science for effective epidemic response. Nature 2019; 575:130-136.

17. FAO, IFAD, UNICEF, WFP and WHO. The State of Food Security and Nutrition in the World 2020. Transforming food systems for affordable healthy diets. Rome: FAO; 2020. 320p.

18. Bittman M. Animal, vegetable, junk. A history of food, from sustainable to suicidal. Boston: Houghton Mifflin Harcourt; 2021. 364p.

19. Leão M, Maluf RS. Effective Public Policies and Active Citizenship: Brazil's experience of building a Food and Nutrition Security System. Brasília: ABRANDH; 2012. $73 \mathrm{p}$.

20. Organização das Nações Unidas para a Alimentação e a Agricultura (FAO). O estado de segurança alimentar e nutricional no Brasil: um retrato multidimensional. Brasília: FAO; 2014. 90p.
21. Rocha C, Jaime PC, Rea M. How Brazil's political commitment to nutrition took shape (Panel 1.5) In: International Food Policy Research Institute. Global Nutrition Report 2016: From Promise to Impact: Ending Malnutrition by 2030. Washington, DC: IFPRI; 2016.

22. Jaime PC, Delmuè DCC, Campello T, Silva DO, Santos LMP. A look at the food and nutrition agenda over thirty years of the Unified Health System. Cien Saude Colet 2018; 23(6):1829-1836.

23. World Health Organization (WHO). Food and Agriculture Organization of the United Nations. Preparation and use of food-based dietary guidelines. Geneva: WHO; 1998. 108p.

24. Gulland A. Dietary guidelines should encourage a healthy planet. BMJ 2017; 356:j1254.

25. Brazil. Ministry of Health. Dietary Guidelines for the Brazilian population. 2nd ed. Brasília: Ministry of $\mathrm{He}-$ alth; 2014. 156p.

26. Monteiro CA, Cannon G, Moubarac JC, Martins AP Martins CA, Garzillo J, Canella DS, Baraldi LG, Barciotte M, Louzada ML, Levy RB, Claro RM, Jaime PC. Dietary guidelines to nourish humanity and the planet in the twenty-first century. A blueprint from Brazil. Public Health Nutr 2015; 18(13):2311-2322.

27. Monteiro CA, Jaime PC. Brazilian Food Guide attacked. Now, overwhelming support for the Guide in Brazil and worldwide. World Nutrition 2020;11(4):9499.

28. The Intergovernmental Panel on Climate Change (IPCC). Climate Change 2014 - Synthesis Report. Contribution of Working Groups I, II and III to the Fifth Assessment Report of the Intergovernmental Panel on Climate Change. [cited 2021 July 05]. Geneva: IPCC; 2014.

29. Bulkeley H. Navigating climate's human geographies: Exploring the whereabouts of climate politics. Dialogues Hum Geogr 2019; 9(1):3-17.

30. Climate Emergency Declaration. Climate emergency declarations in 1,990 jurisdictions and local governments cover 1 billion citizens; 2021. [Internet]. [cited 2021 Jun 19]. Available from: https://climateemergencydeclaration.org/climate-emergency-declarationscover-15-million-citizens/

31. Serrao-Neumann S, Di Giulio G, Choy DL. When salient science is not enough to advance climate change adaptation: Lessons from Brazil and Australia. Environ Sci Policy 2020; 109:73-82.

32. Giddens A. Risk and responsibility. Mod Law Rev 1999; 62(1):1-10

33. Beck U. Sociedade de risco: rumo a uma outra modernidade. 2. ed. São Paulo: Editora 34; 2010

34. Marques L. Capitalismo e colapso ambiental. 2.ed. Campinas: Editora Unicamp; 2016.

35. Ventura D, Giulio GM, Rached DH. Lessons from the COVID-19 pandemic: sustainability is an indispensable condition of Global Health Security. Ambient Soc 2020b; 23: e0108.

36. Brown K, Westaway E. Agency, capacity, and resilience to environmental change: lessons from human development, well-being, and disasters. Annu Rev Environ Resour 2011; 36: 321-342. 
37. Brescia R, Marshall JT. How cities will save the world: urban innovation in the face of population flows, climate change and economic inequality. 1. ed. Abingdon: Routledge; 2016.312 p.

38. Broto VC. Energy landscapes and urban trajectories towards sustainability. Energy Policy 2017; 108:755764.

39. Ford JD, Berrang-Ford L, Paterson J. A systematic review of observed climate change adaptation in developed nations. Clim Chang 2011; 106:327-336.

40. Eakin HC, Patt A. Are adaptation studies effective, and what can enhance their practical impact? WIREs Clim Chang 2011; 2(2):141-153.

41. Morin E. A mundialização é uma interdependência sem solidariedade. L'OBS, 19-25/3/2020 - Entrevista concedida a David Le Bailey e Sylvain Courage. Tradução: Edgard de Assis Carvalho.

42. Settele J, Díaz S, Brondizio E. COVID-19 - Stimulus Measures Must Save Lives, Protect Livelihoods, and Safeguard Nature to Reduce the Risk of Future Pandemics. Ipbes 2020; [cited 2020 May 13]. Available from: https://ipbes.net/covid19stimulus.

43. Nunes J. A pandemia de COVID-19: securitização, crise neoliberal e a vulnerabilização global. Cad Saude Publica 2020; 36(5):e00063120.

44. Ribeiro H, Vasconcellos MP, Ventura DL. Ideas of wellness in Brazil: a concept under deliberation. In: (RIS) Research and Information System for Developing Countries. Health, nature and quality of life towards BRICS Wellness Index. Nova Delhi: BRICS; 2016. [cited 2021 Jul 29]. Available from: ris.org.in/ health-nature-and-quality-life
45. Cox DTC, Shanahan DF, Hudson HL, Plummer KE, Siriwardena GM, Fuller RA, Anderson K, Hancock S, Gaston KJ. Doses of Neighborhood Nature: the benefits for mental health of living with nature. Bioscience 2017; 67(2):147-155.

46. Frumkin H. Contato con la naturaleza? Um beneficio para la salud? In: Salud Ambiental de lo global a lo local. Washington: Organización Panamericana de la Salud; 2010 .

47. Joly CA, Queiroz HL. Pandemia, biodiversidade, mudanças globais e bem-estar humano. Estud Av 2020; 34(100):67-82.

48. Glikson A. Recreational Land Use. Thomas WL. (ed) Man's role in changing the face of the earth. v. 2. University of Chicago Press: 1956; 896-914.

49. Pereira R. Interior entra no radar das empresas. Custo de vida menor e facilidade do home office atraem trabalhadores e companhias. O Estado de São Paulo; 2021 25 Abril; Economia B5.

Article submitted 09/08/2021

Approved 30/08/2021

Final version submitted 01/09/2021

Chief editors: Romeu Gomes, Antônio Augusto Moura da Silva 